\title{
比較判断におよぼす系列効果 順応水準理論による検討
}

Helson's adaptation level(AL) theory is a general attempt to understand judgment process relating physical and sensation magnitudes. The distinctive feature of $\mathrm{AL}$ theory is to explain the relativity of judgment by assuming $\mathrm{AL}$ concept, which is the reference level of judgment established within the behaving organism. And Helson defined mathematically the $\mathrm{AL}$ as a weighted geometric mean of all background stimuli. This experiment was designed to study the effect of stimulus series on comparative judgment of lifted weights in terms of the AL model. The results indecate that comparative judgment depend on the stimulus series, and the AL model can account for the empirical data quite well.

順応水準説 (Adaptation-level theory) は，重さ，明るさなどの刺激を分類，あるいは範瞦化する という人間の判断過程のモデル化の一つの試みであり,その特徵は, 判断に及ぼす背景の影響を記述し ている点にある. 本研究では, 重量の比較判断事態に, 順応水準の対数平均モデルを適用し, 実験によ うて，次のような結果を得た；(1)モデルはデータによく適合し，代と增山1)の結果を確認した. (2)実験 に使用された刺邀の系列が，判断に影響することが見出された。

\section{1. はじめに}

食品の味や匂いなどの検査には人間の感覚器官が用い られるが，感覚による判定では，ノイズとしての背景の 効果が，結果にかなり大きく作用する. そこで，例えば 個人差, 体の調子, 気分などのような, ノイズとしての 背景の効果を考慮に入れた感覚器官の応答の特性, ある いは中枢部における判断機能そのものの特性を問題に する必要がある. Helson, H. の提唱した順応水準説 (Adaptation level theory, AL 説と略す) は, 判断に及 ぼす背景刺激の影響に視点を置き，心的機能としての判 断過程を記述，モデル化しょうとする一つの試みであ る.

* 昭和51年 4 月 15 日

** 東京都立大学人文学部 The Faculty of Social Sciences and Humanities. Tokyo Metropolitan University
AL 説では, 種々の判断事態において, 内的判断基準 を想定し，これを順応水準 (Adaptation level, AL) と 呼ふ. 例えば, ある重量刺激に対して, 重いという反応 が得られることは, 重さ次元で重くも軽くもないゼロ点 （順応水準）を仮定し, そのゼロ点よりも知覚された重 量刺激が重かったからである，と説明される．また， $\mathrm{AL}$ 説では, 種々の背景が, この AL を規定すると仮定 している. 例えば, 重い物に慣れた人は, AL が重い方 向にいわば㮌応しているために, 軽いという反応が比較 的多くなると予想できる. さらに, Helson'2) はこの $\mathrm{AL}$ が判断に影響するすべての刺激の加重幾何平均になると して, 判断に及ぼす背景効果を数量的に表現した.

この AL 説に関する研究は, 絶対判断の事態が中心て あったが，代と増山 (1) 一，一対比較のような比較判断事 態に, Helson 以来の AL の対数平均モデルを適用して, その有効性を示した. また，比較すべく提示された刺激 以外の何らかの背景が判断に影響を与えているというこ 
刺激系列

の範囲

(系列番号)

標準刺激番号

重量刺激

錆の番号

自然対数

物理量 $(\mathrm{g})$
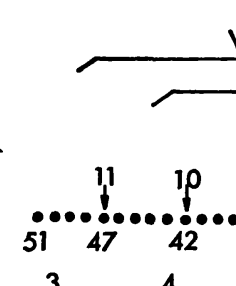

VII

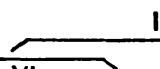

IV
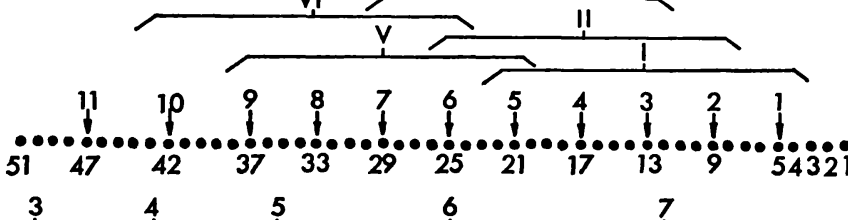

5

100
6

500

図 1 実験に使用された刺激の系列

とを見出した．本実験は，この背景の効果とは，実験に 使用された刺激の系列全体の影響である，という仮説を 検証することが目的である.

ここでいう比較判断とは，基準となる刺激（標準刺激 という）を先ず提示し，次に提示される刺激（比較刺激 という）が，標準刺激に比較してどのように感じられた かを判断させる事態であり， AL 説に従えば，物理的な 標準刺激が示されていても，人間の内的判断基準は標準 刺激とその他の背景刺激との総合によって形成される AL であるということになる.

\section{2. 理論モデル}

Helson ${ }^{2)}$ による加重対数平均モデルを一般的な形式で 表わすと, 次のようになる;

$$
\log \mathrm{AL}=\sum_{i=1}^{n} w_{i} \log A_{i} \quad\left(\sum_{i=1}^{n} w_{i}=1\right)
$$

ここで $A_{i}$ は種々の背景刺激を示し， $w_{i}$ はその重みで ある. また，ある刺激 $(X)$ の判断值 $(J)$ は, 基準点で ある AL との対数尺度上での差によって表現される ;

$$
J=k(\log X-\log \mathrm{AL})
$$

$k$ は定数である.（2）式はフェヒナー公式の絶対閾を AL に置き換えた形をしており，また，(1) 式，(2）式 ともに物理量を対数変換している点, 両式は共通の基盤 を持っている.

代と増山 ${ }^{1)}$ における比較判断基準のモデルは，次のよ うなものであった；

$\log \mathrm{AL}=p \log S+(1-p) \log A^{\prime}$

ここで $S$ は標準刺激を， $p$ はその重みを表わし， $A^{\prime}$ は 標準刺激以外のすべての背景の効果を表わす残余刺激で ある. 重さの継時比較判断実験の結果，（3）式はデータ によく適合し， $A^{\prime}$ (残余効果) の仮定の有意性が示され た.すなわち，標準刺激以外の何等かの背景効果が判断 に影響を及ぼしていると考えられる. 本研究の目的は,

\footnotetext{
* 本稿中の対数はすへてて自然対教とする
}

この背景効果 $\left(A^{\prime}\right)$ が実験に使用 された刺激の系列（Bで表わす） に規定される，という予測を確か めること,およびそれ以外の残余 効果（ここでは $R e$ で表わす）を 仮定することに意味があるか否か を検討することである.このこと を対数平均モデルによって表現す れば ; $\log A^{\prime}=r \log B+(1-r) \log R e$ となる. $r$ は系列効果の重みを示す.この（4) 式を（3） 式に代入すると；

$\log \mathrm{AL}=p \log S+(1-p) r \log B+(1-p)(1-r) \log R e$ となり,ここで $(1-p) r=q$ と置くと；

$\log \mathrm{AL}=p \log S+q \log B+(1-p-q) \log R e$ (5) となり, 系列効果を考慮に入れた比較判断の $\mathrm{AL}$ モデル が定まる. この（5）式が検証すべき直接の理論モデルで ある. 解析には回帰分析の手法が用いられる.

\section{3. 実験方法}

一般的解析手順 : 重量の継時比較判断実験により，まず (2) 式の仮定に従い, 刺激 $(X)$ とその判断值 $(J)$ と の関係で, $\mathrm{AL}$ を推定する. この実測の $\mathrm{AL}$ は, 精神物 理学的な概念である主観的等価值 (point of subjective equality, PSE) と意味的に等しい. 次に，(5) 式に従 い,この実測の $\mathrm{AL}$ を従属変数とし, 標準刺激 $(\log S)$ と系列効果 (実験に使用した系列刺激の対数平均 值, $\log B)$ との 2 つを独立変数として, 回帰傾向を検討し, 残余効果 $(\log R e)$ の有意性を検定する.

刺激：16.5 g から $2,522 \mathrm{~g}$ までの，心理的にほぼ等間隔 だと感じられる 51 個の重量刺激を用いた。錘は円筒形 で, 直径 $7.8 \mathrm{~cm}$, 高さ $5.8 \mathrm{~cm}$ である. 図 1 のように, 51 個の刺激のうちの 11 個を標準刺激と定め, その刺激 を含めて上下 4 個ずつ計 9 個の刺激を, その標準刺激に 対する比較刺激とした。ささらに，5個ずつの隣合った標 準刺激を組合わせて，7系列の刺激の系列を設定した。 つまり, 1 つの鍾がある時には, 標準刺激となり, 別の 時には異なった標準刺激に対する比較刺激になるという 如く，何通りにも利用されたことになる. 標準刺激, 系 列ともに重い方から順に番号をつければ, 第 I 系列は, 最とも重い系列であり，標準刺激番号 1 から 5 までの範 囲で，比較刺激を含めれば，刺激番号 1 から 25 までの 釷によって構成されることになる. また，第II系列は， 


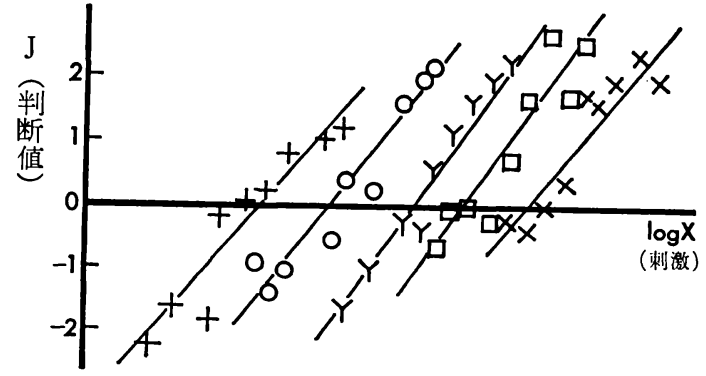

図 2 刺激 $(\log \times)$ と判断值（ $\mathrm{J} ）$ との関係（被験 者(1)

第 2 標準から第 6 標準まで刺激番号 5 から 29 までによ って構成されることになる.

被験者 : 都立大学心理学専攻の学生 7 名.

手続き： 7 名の被験者を無作為に 7 つの系列に割り当て た. 練習試行は 25 回とし, 各系列ごとの 45 刺激対（5 標準刺激 $\times 9$ 比較刺激）を 5 反復提示した. すなわち, 各系列とも 225 個の判断值が得られることになり, 実験 では, 225 個の刺激対を全体からランダムに, 標準刺激 を先, 比較刺激を後に順に提示した. 判断は,「非常に
重い」「重い」「やや重い」「同じくらい」「やや軽い」 「軽い」「非常に軽い」の 7 カテゴリーのいずれかによ って報告された. 提示時間は, 標準, 比較刺激ともに 2 秒で，間隔時間は 4 秒とした. 実験時間は 1 被験者につ き 50 分を 2 回, 計 100 分とし, 実験は 2 日間に分けて 行ない, 25 試行ごとに約 2 分の休息をとった. その他, 代と増山1)の方法に準じた.

解析方法 : 得られたカテゴリ一判断值の各々を, 重い方 から順に，3，2， 1, 0, - 1, $-2,-3$ の数值に置き換 える. 5 反復提示であるから， 1 標準刺激について，45 断判值（ 9 比較刺激 $\times 5$ 反復）が得られることになる. この 45 個の判断值から, (2) 式の仮定に従って回帰直 線を求め, 標準刺激毎に AL を推定する. すでに述へた ように,この值を従属変数とし，(5) 式の未知数 $p, q$, および $R e$ を最小二自乗法によって推定し, 適合度を検 討する.

\section{4. 結果および考察}

4-1 刺激と判断值との関係（(2) 式について） 実験の結果を (2) 式に従い, 刺激 $(X)$ とその判断值

表 1 実測のALの自然対数

\begin{tabular}{c|r|c|c|c|c|c|c|c|c|c|c|c} 
r 標準刺激 & 3.434 & 4.209 & 4.881 & 5.220 & 5.627 & 5.999 & 6.363 & 6.640 & 6.956 & 7.230 & 7.527 \\
\hline $\begin{array}{c}\text { 系列 } \\
\text { 番号 }\end{array}$ 対数平均 & 11 & 10 & 9 & 8 & 7 & 6 & 5 & 4 & 3 & 2 & 1 \\
\hline VII & 4.663 & 3.656 & 4.113 & 4.752 & 5.054 & 5.471 & & & & & \\
\hline VI & 5.175 & & 4.446 & 4.965 & 5.222 & 5.559 & 5.900 & & & & \\
\hline V & 5.609 & & & 4.982 & 5.189 & 5.508 & 5.935 & 6.308 & & & & \\
\hline IV & 5.969 & & & & 4.459 & 5.703 & 5.976 & 6.224 & 6.531 & & \\
\hline III & 6.312 & & & & & 5.673 & 5.944 & 6.261 & 6.473 & 6.731 & & \\
\hline II & 6.634 & & & & & & & 6.011 & 6.297 & 6.545 & 6.845 & 7.085 \\
\hline I & 6.941 & & & & & & & 6.678 & 6.801 & 6.957 & 7.077 & 7.352 \\
\hline
\end{tabular}

表 2 直線 $(\mathrm{J}=\mathrm{k}(\log \mathrm{X}-\log \mathrm{AL}))$ の不適合性検定の $\mathrm{F}$

\begin{tabular}{c|c|c|c|c|c|c|c|c}
\hline 被験者 & (1) & (2) & (3) & (4) & (5) & (6) & (7) \\
\hline \multirow{3}{*}{$\mathrm{F}$} & 1.587 & 1.036 & 1.779 & 0.821 & 0.762 & 0.995 & 1.385 \\
の & 0.150 & 1.939 & 0.685 & 0.698 & 0.927 & 1.061 & 0.449 \\
& 1.589 & $2.337^{*}$ & $3.381^{* *}$ & 1.771 & 1.353 & 1.220 & 1.809 \\
值 & 1.612 & 1.040 & 0.373 & 1.132 & 0.422 & 1.540 & 1.602 \\
& $2.296^{*}$ & 1.071 & 1.177 & 0.012 & 0.965 & 0.978 & $3.008^{*}$ \\
\hline
\end{tabular}




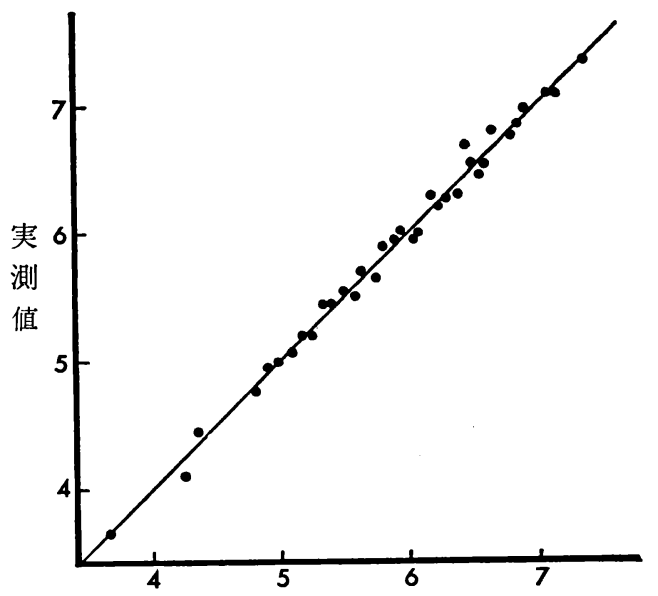

予測值 (自然対数)

図 3 実測值と予測値との関係 $\left(\mathrm{R}^{2}=0.992\right)$

（J）との関係で表わすと, 図 2 のようになった（被験 者(1)ついて，絽返しの平均がプロットしてある). 回 帰直線の横軸との交点に推定の AL の值が示されている が,このようにして得られた值を, 実験条件である標準 刺激 $(\log S)$ および系列刺激值（系列刺激の幾何平均の 対数）とともに表 1 に示す. 直線の不適合性の検定が表 2 であり，(2) 式の仮定が無意味とはいえないことがわ かる.

図 2 を代と増山1) の結果と比較すると, 本結果の方が 点がより直線的に布置している. これは, 代と增山が刺 激重量を対数等間隔にとったのに対し，本実験ではそれ を修正し, 重い方をより密にして (図 1 参照) 弁別的に 等間隔に感じられるようにしたことによると考えられ る.これら 2 つの実験結果は， $0, \pm 1, \pm 2, \pm 3$ とい う数值を形容詞に対応させる等間隔スケールが, 設定さ
れた刺激間隔の違いによって, 判断者に異なって理解さ れることを示している.

\section{4-2Ａ L モデルの検証}

表 1 の数値から，（5）式の仮定に従い，次のような回 帰方程式を得た；

$\log \mathrm{AL}=0.807 \log S+0.192 \log B$ $+0.001 \log \left(1.0 \times 10^{-6}\right)$

決定係数（重相関係数の 2 乗) $R^{2}=0.992$

表 1 からわかるように，本実験では，その計画の上か ら, 標準刺激 $(\log S)$ と系列刺激 $(\log B)$ とは見かけ 上，相関を持っている. したがって, $\log S$ と $\log B$ の 標準偏回帰係数は，それぞれ，0.867，0.166 となった. 図3は（6）式によって予測される AL の值と, 表 1 に ある実測值との関係を示したものである. 残差に特別な 傾向は見られない，表 3 はその分散分析表である.

回帰全体は有意であり，きわめて適合度が高く，モデ ルの有効性が示されている. 標準刺激 $(\log S)$ の項, 系 列刺激 $(\log B)$ の項ともに統計的に有意である. 比較判 断の AL を規定する要因として，標準刺激効果のほか に,ここで新に系列効果の有意性が示された.

なお，ここで示された適合度（決定係数）は，標準刺 激の効果に大きく依存している.ここで, 標準刺激の効 果とは，物理的判断基準である標準刺激の值が大きくな ると，それにつれて観察者の主観的判断基準 (AL) が大 きくなる，という常識的な傾向を意味している.したが って, 次に標準刺激の効果と系列効果とを別々に取り扱 い, 系列効果の意味を明確にし， あわせて残余効果 ( $\log R e)$ の有意性を検討する．その方法としては，(5) 式の標準刺激 $(\log S)$ の重み $p$ を各系列を通じて一定 であると考えずに，(3) 式と（4）式とを別々にデー夕に あてはめるというやり方をとる.

表 3 回㷌分析の分散分析表

\begin{tabular}{l|r|r|r|r}
\hline 変 動 因 & \multicolumn{1}{|c|}{$\mathrm{SS}$} & $\mathrm{df}$ & $\mathrm{MS}$ & $\mathrm{F}$ \\
\hline 回帰 & 26.3098 & 2 & 13.1549 & $1930 .{ }^{* *}$ \\
(系列効果) & 0.2582 & 1 & 0.2582 & $37.9^{* *}$ \\
(系列以外) & 26.0516 & 1 & 26.0516 & \\
(標準刺激効果) & 6.8198 & 1 & 6.8198 & $100 .^{* *}$ \\
(標準以外) & 19.4900 & 1 & 19.4900 & \\
\hline 誤差 & 0.2179 & 32 & 0.00681 & \\
\hline 全体 & 26.5277 & 34 & & \\
\hline
\end{tabular}

** 1\%危険率で有意

24 人間工学 Vol.12, No.1 ('76) 


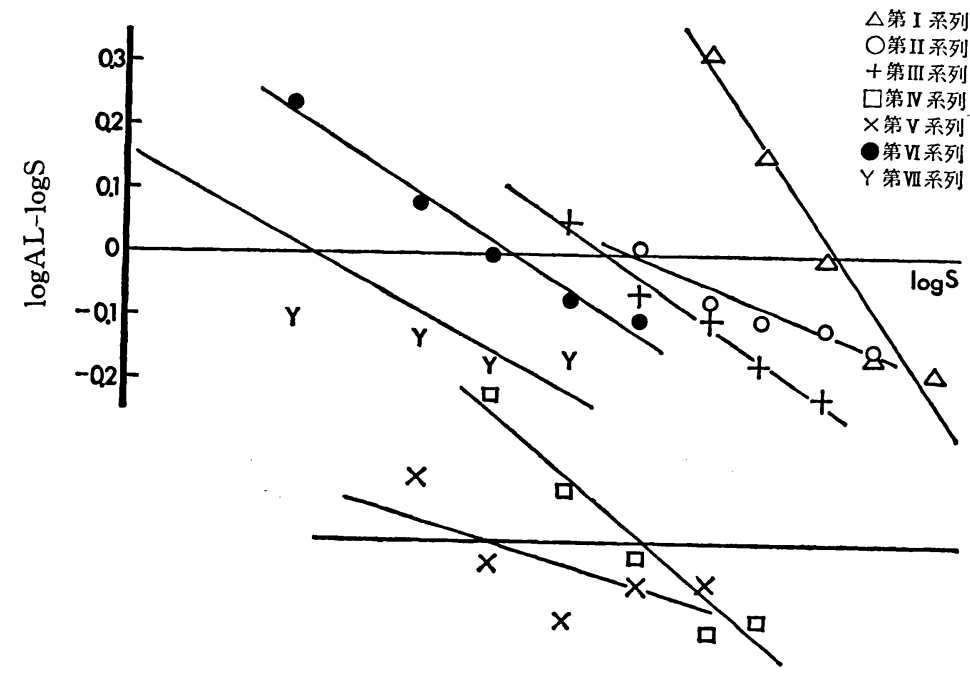

図 4 標準刺激 $(\log S)$ からの変位傾向
表 4 標準刺激からの変位の検定

\begin{tabular}{c|c}
\hline 系 列 & $\mathrm{t}$ \\
\hline $\mathrm{I}$ & $8.23^{* *}$ \\
II & $6.59^{* *}$ \\
III & $16.32^{* *}$ \\
IV & $5.97^{* *}$ \\
V & 1.54 \\
VI & $10.93^{* *}$ \\
VII & $3.22^{*}$ \\
\hline
\end{tabular}

** 1 \%危険率で有意

* 5 \%危険率で有意

\section{4-3 系列効果亡残余効果}

$\mathrm{AL}$ が標準刺激から，どのように変位しているのか, ということに視点を置くと，(3）式から次の式が導かれ る;*

$\log \mathrm{AL}-\log S=(p-1) \log S+(1-p) \log A^{\prime}$ この式に従い, $\mathrm{AL}$ の標準刺激からの変位（log $\mathrm{AL}$ $\log S)$ を標準刺激 $(\log S)$ に対して，プロットしたのが 図 4 である. 系列毎に回帰直線が示してあり，回帰の検 定の結果が表 4 である. 系列 VやVIIどに，点の布置が 下に凸である特徵的な傾向が見られるが，他はほとんど 直線的である.これらの回帰直線の横軸との交点に（7） 式の $\log A^{\prime}$ (標準刺激以外の効果) が示されているが, 回帰が有意であることは， $A^{\prime}$ の仮定の有意性を示して いる.このことは, 代と増山融によって確かめられた傾 向を改めて確認したことになる.

このようにして得られた $\log A^{\prime}$ の值を，(4) 式の検 討のため, $\log B$ (実験に使用された刺激の対数平均值) に対してプロットすると，図 5 のようになる. $\log A^{\prime}$ (標準刺激以外の効果) が $\log B$ (系列効果) に依存する ことが理解される. さらに，(4) 式の $\log R e$ (残余効 果) は，統計的に有意とならなかった（図 5 で，回帰直 線と $\log A^{\prime}=\log B$ の直線とは，統計的に有意に区別で きなかった)。

以上のことから，本実験結果では，継時的比較判断の AL を規定する要因として，標準刺激と実験に使用され

* 時間誤差 (time error) の AL モデルによる表現であると 考える。

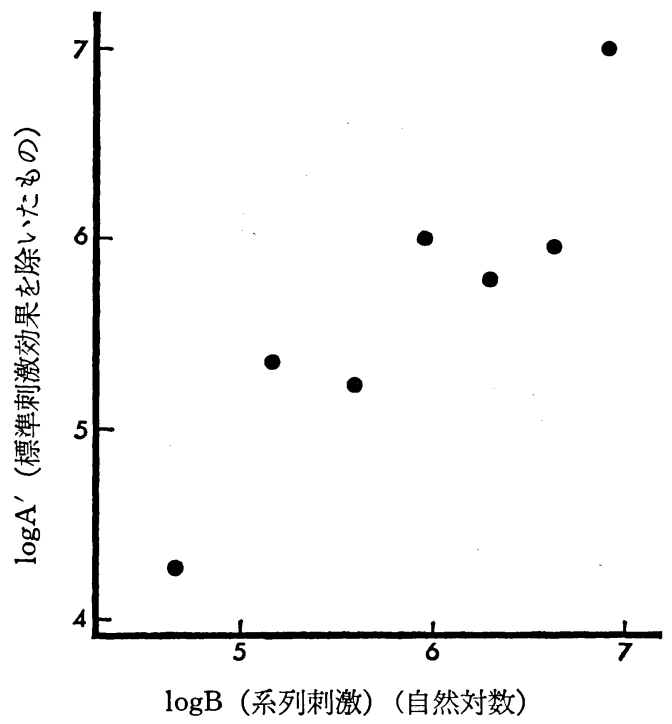

図 5 系列効果

た刺激の系列全体との 2 つが見出され，他の影響は見出 されなかったが，残余効果 $(\log R e)$ の検討については, 個人差の効果を誤差から除くようには計画されていなか ったことに，注意しなくてはならない。

\section{5. 結論と今後の問題}

（1）本実験では，AL の対数平均モデルが，重量の継 時比較判断のデータに対して, 高い適合度を示したが, すでに述べたように，モデルは標準刺激と判断刺激の効 
果を除いた背景の効果を記述するのに有効でなくてはな らない.この意味で，図4に示されたような ALの標準 刺激から変位傾向，あるいは系列効果が有意であったこ

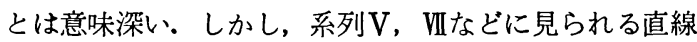
性からの系統的なずれの意味に関して，今後検討してい く必要があろう.

（2）ここでは，系列効果として系列刺激の幾何平均值 を用いたが，AL 説の理論的文脈から撖密に考えれば, 系列効果に関し，次のように考えることができる.

ある時点における $\mathrm{AL}\left(\log \mathrm{AL}_{n}\right)$ は，その時点の標準 刺激 $\left(\log S_{n}\right)$ と比較刺激 $\left(\log X_{n}\right)$ ，およびそれまでの $\mathrm{AL}\left(\log \mathrm{AL}_{n-1}\right)$ によって形成される;

$\log \mathrm{AL}_{n}=p \log X_{n}+q \log S_{n}+r \log \mathrm{AL}_{n-1}$

ただし，ここでの重みを表わす記号 $p, q, r$ は，(5) 式 のそれらの記号とは別のものとする. これらの重みが各 時点で一定であるとし, AL の一つ前の值を順次代入し ていくと；

$$
\begin{aligned}
& \log \mathrm{AL}_{n}=p \sum_{i=1}^{n} r^{n-i} \log X_{i}+q \sum_{i=1}^{n} r^{n-i} \log S_{i} \\
& +\boldsymbol{r}^{n} \log \mathrm{AL}_{0}
\end{aligned}
$$

という式を得る．ここで $\mathrm{AL}_{0}$ とは，実験直前に各個人 が持っている日常的なゼロ点である.（9）式は，ある時 点のALがそれまでに用いられた刺激に規定されること を示しており，r<1 ならば（本実験結果では $r^{n} \fallingdotseq 0.01$ と予想される), 時間的に遡っていくと刺激効果が小さ くなっていくことを表現している.この (9) 式の右辺か ら, ある時点の標準刺激の項 $\left(q \log S_{n}\right)$ と比較刺激の項 $\left(p \log X_{n}\right)$ を除いたものが，ここでいう系列効果と残余
効果とを意味しており，本実験で用いた系列刺激の幾何 平均值としての系列効果とは，(9) 式の近似的意味をも つものであるといえる. 経験効果の蓄積されていく過程 を明らかにしていくためにも, 時系列的に対数平均モデ ルを検討していく必要があると思われる.

（3）判断過程の内的特性を明らかにしていくために, 今後，判断行動の内実をなす種々の心的機能（いわゆる 知覚, 記憶, あるいは決定 (decision) などの問題が関 わってくると考えられる)に則して，AL モデルを検討 していく必要があるだろう.

（4）本実験によって，比較判断事態で人間が判断の基 準としているALは, 比較されるべく提示されている標 準刺激に大きく規定され, その背景効果として, 刺激系 列全体の影響が見出された.このことは，AL モデルが 線型モデルであることから, 回帰分析などの統計的な有 意性検定によって示された. また, それ以外の背景効果 は見出されなかったが, 個人によって日常的なゼ口点 （順応水準）が異なっているのではないか，と予想でき る. 今後検討したい問題である.

付記：この論文をまとめるにあたっての增山英太郎先生 の御助力に対して, 感謝いたします.

\section{文 献}

1）代, 增山；比較判断事態における順応水準理論の実 験的検討, 人間工学, Vol. 11, No. 1, 17-22, 1975.

2) Helson, H. ; Adaptation-level theory, 125-231, Haper, New York, 1964. 